\title{
Clinical significance of Wip1 overexpression and its association with the p38MAPK/p53/p16 pathway in NSCLC
}

\author{
SHIZE YANG, SIYUAN DONG, XIAOHAN QU, XINWEN ZHONG and QIGANG ZHANG \\ Department of Thoracic Surgery, The First Affiliated Hospital of China Medical University, \\ Shenyang, Liaoning 110000, P.R. China
}

Received September 23, 2015; Accepted September 30, 2016

DOI: $10.3892 / \mathrm{mmr} .2016 .6032$

\begin{abstract}
Wip1 is deregulated in numerous human malignancies. However, its roles in non-small cell lung cancer (NSCLC) remain unclear. In the current study, the expression of Wip1 was investigated in NSCLC and its clinical significance was detected. Immunohistochemical staining was used to measure the expression of (wild-type p53 induced phosphatase 1) Wip1, p38 mitogen-activated protein kinase (MAPK), p53, p16 protein in a group of 60 NSCLC and 20 normal lung tissues. In addition, western blotting was performed to detect the Wip1 protein in fresh tissues. The correlations between clinical characteristics and Wip1 expression were analyzed using SPSS, version 16.0 software. The expression of Wip1 was positive in $63.3 \%(38 / 60)$ of NSCLC tissues, and in none of the normal lung tissues $(0 / 20 ; \mathrm{P}<0.01)$. In addition, Wip1 overexpression was significantly associated with tumor length and differentiation ( $\mathrm{P}=0.008$ and 0.03 , respectively). The expression of Wip1 was negatively correlated with that of p38MAPK, p53 and p16 ( $r=-0.284,-0.352$ and -0.348 , respectively). The results of the current study demonstrated that Wip1 was frequently overexpressed in NSCLC, which may serve an essential role in the p38MAPK/p53/p16 signaling pathway.
\end{abstract}

\section{Introduction}

Lung cancer is one of the most common malignancies worldwide, and approximately $85 \%$ new cases are non-small cell lung cancer (NSCLC). Despite therapeutic advances, the majority of patients with lung cancer undergo locally advanced and distant metastasis, with an overall five-year survival rate less than $20 \%$ (1). Thus, it is imperative to further investigate the molecular mechanisms underlying the progression of NSCLC.

Correspondence to: Dr Qigang Zhang, Department of Thoracic Surgery, The First Affiliated Hospital of China Medical University, 155 Nanjing Road, Heping, Shenyang, Liaoning 110000, P.R. China E-mail: zqg6256@163.com

Key words: Wip1, NSCLC, p53, p16, p38MAPK
The protein phosphatase wild-type p53 induced phosphatase 1 (Wip1) is a major serine/threonine phosphatase of the protein phosphatase $2 \mathrm{C}$ family encoded by the protein phosphatase, $\mathrm{Mg}^{2+} / \mathrm{Mn}^{2+}$ dependent $1 \mathrm{D}$ gene (2). The overexpression and amplification of Wip1 had been previously identified in numerous types of human cancer including medulloblastomas (3), clear cell renal cell carcinoma (4), colorectal cancer (5) and breast cancer (6). In addition, Bulavin et al (7) demonstrated that Wip1 functioned as a proto-oncogene in breast cancer. ATM serine/threonine kinase is one of the master regulators of the DNA damage-induced response signaling pathway (8), which was previously identified to be inactivated by Wip1 expression and potentially reduced the rate of tumor evolution (9). In addition, p38 mitogen-activated protein kinase (MAPK) was considered as a downstream target of Wip1, which regulated the cell cycle by inhibiting cyclin D1 under stress (10) and directly suppressed p53 activities through Ser33 and Ser46 dephosphorylation by controlling cellular apoptosis (8). An additional study further confirmed that Wip1 overexpression in mesenchymal stem cells diminished the p38MAPK activity and reduced the levels of p16 (11). Accordingly, Wip1 overexpression was identified to suppress checkpoint kinase 1 (CHK1) activity, whereas downregulation of Wip1 elevated CHK1 to activate the $\mathrm{G}_{2} / \mathrm{M}$ checkpoint following DNA damage (12).

However, the expression and functions of Wip1 in NSCLC remain unclear. In the current study, the expression of Wip1 was identified in NSCLC, and its clinical significance was determined.

\section{Materials and methods}

Tissue collection. Between April and September 2014, a total of 60 NSCLC tissues were obtained from patients who underwent tumor resection at the First Affiliated Hospital of China Medical University (Heping, China). The patients were comprised of 34 males and 26 females with a mean age of 58.6 years (range, $42-72$ years). None of the 60 patients received any chemotherapy or radiotherapy prior to the operation. All cases were pathologically diagnosed and staged according to the TNM classification system (13). The 60 fresh specimens of tumor tissue and 20 adjacent normal lung tissues $(5 \mathrm{~cm}$ distance from the cancer) were immediately obtained during the surgery: One part was stored in $4 \%$ paraformaldehyde 
solution and then embedded in $10 \%$ paraffin for immunohistochemistry, and the other part was preserved in liquid nitrogen for western blot analysis.

In the cancer group, 34 cases were identified with lymph node involvement $(\mathrm{N}+)$.

As for TNM stage, 44 cases were at stage I II and 16 were at stage III IV. In addition, 16 cases were highly differentiated and 44 cases exhibited with moderate or low differentiation. There were 40 cases, which presented with a tumor length larger than $3 \mathrm{~cm}$. In addition, there were 6 cases who presented with distant metastasis. The experimental protocol was established, according to the ethical guidelines of the Helsinki Declaration and was approved by the Human Ethics Committee of the First Affiliated Hospital of China Medical University. Written informed consent was obtained from individual participants.

Main reagents and immunohistochemistry. The rabbit anti-human Wipl monoclonal antibody was purchased from Santa Cruz Biotechnology, Inc. (Santa Cruz, CA, USA; cat. no. sc-130655). The monoclonal mouse antibodies against p16 (cat. no. 6598), p53 (cat. no. 9284), phosphorylation of p38 (cat. no. 9215) and GAPDH (cat. no. 2118) were purchased from Cell Signaling Technology, Inc. (Danvers, MA, USA). Immunohistochemistry kit and Bicinchoninic Acid (BCA) Protein Extraction kit were obtained from OriGene Technologies, Inc. (Beijing, China). RIPA buffer was purchased from Sigma-Aldrich (Merck Millipore, Darmstadt, Germany).

A 4- $\mu$ m section was prepared from the paraffin-embedded block and dehydrated, and incubated in $3 \%$ hydrogen peroxide for 12 min to block endogenous peroxidase, followed by trypsin treatment for $18 \mathrm{~min}$. A $10 \%$ goat serum was introduced at room temperature for $20 \mathrm{~min}$, and the Wipl antibody (1:100) was added to the tissues and incubated at $4{ }^{\circ} \mathrm{C}$ overnight. As for the negative control, the primary antibody was replaced with PBS. The secondary antibodies in a ready to use kit (SP-9000; ZSGB-BIO, Beijing, China) were added as appropriate and 3,3'-diaminobenzidine staining was visualized using the hematoxylin stain. Two pathologists scored the slides respectively. For Wip1 staining assessment, samples with more than $10 \%$ cells that were yellow/brown-stained were classified as positive.

Western blot analysis. Western blot was performed to detect the expression of Wipl in fresh tissues. The RIPA buffer was used to extract the total protein. Next, the protein concentrations were quantified by the BCA Protein Assay kit. A total of $50 \mu \mathrm{g}$ total protein of each sample was loaded onto the $10 \%$ SDS-PAGE and transferred to PVDF membranes (EMD Millipore, Billerica, MA, USA). Following blocking for $1 \mathrm{~h}$ in $5 \%$ non-fat milk, the membranes were incubated with primary antibodies overnight at $4^{\circ} \mathrm{C}$ (Wip1, 1:200; GAPDH, 1:1,000). On the second day, the membranes were incubated with the secondary antibodies followed by ECL chemiluminescence (Qihai Biotec, Shanghai, China). The results were analyzed using Gel-Pro-Analyzer software version 6.3 (Media Cybernetics, Inc., Rockville, MD, USA).

Statistical analysis. All statistical analyses were performed using SPSS software, version 16.0 (SPSS, Inc., Chicago, IL, USA). Fisher's exact test was used to determine the differences
Table I. The expression of Wip1 in cancer tissues and matched normal tissues.

\begin{tabular}{lcccc}
\hline Group & Total & Wip1 +ve & Wip1 -ve & P-value \\
\hline Cancer tissue & 60 & 38 & 22 & $<0.001$ \\
Normal tissue & 20 & 0 & 20 & \\
\hline
\end{tabular}

Wip1, wild-type p53 induced phosphatase 1 .

of the Wip1 protein in cancer tissues and normal tissues. The $\chi^{2}$ test was used to assess the association between the clinicopathological parameters. Spearman's rank correlation coefficient was applied to see the correlation between Wip1 and p53, Wip1 and p16, and Wip1 and p38MAPK, respectively. $\mathrm{P}<0.05$ was considered to indicate a statistically significant difference.

\section{Results}

Wipl protein expression in NSCLC and normal tissues. According to the immunohistochemistry data, the Wip1 expression was not detected in normal tissues (Fig. 1A). In NSCLC tissues, Wip1 was stained negative (Fig. 1B), light yellow (Fig. 1C) or yellowish-brown (Fig. 1D and E). Collectively, Wipl was expressed in $63.3 \%$ (38/60) of NSCLC tissue, which was significantly greater than in normal tissues $(0 \% ; \mathrm{P}<0.01$; Table I). Furthermore, the expression of Wip1 was investigated using western blot analysis. The data indicated that there was a significant increase of Wip1 expression in the NSCLC tissues compared with the normal tissues $(\mathrm{P}<0.05$; Fig. 2).

Association between Wipl expression and clinicopathological factors of patients. The associations between Wip1 expression and clinicopathological factors are summarized in Table II. The increased expression of Wip1 indicated a significant association with tumor length $(\mathrm{P}<0.01)$ and degree of differentiation $(\mathrm{P}<0.05)$, which may serve as a necessary prognostic marker for patients. However, no significant correlation was detected between Wip1 and other clinicopathological features including gender, lymph node metastasis, smoking history, age, pathological type, TNM stage and distant metastasis. In addition, western blot analysis demonstrated that were was no correlation between Wipl and pathological types (data not shown; Fig. 2).

Association between Wip1,p53,p16 and p38MAPK. According to the immunohistochemistry data, the expression of p53 was inversely correlated with Wip1 ( $\mathrm{r}=-0.352)$. A total of $16 / 25$ (64\%) tumors with negative Wip1 exhibited strong staining for p53. In contrast, 25/35 (71.4\%) cases with positive Wip1 exhibited weak staining for p53.

Subsequently, whether Wip1 was correlated with the levels of p38MAPK in NSCLC was investigated. Out of 29 Wip1-positive tumors, 21 (72.4\%) did not stain for p38MAPK. On the contrary, only $61.3 \%$ (19/31) of tumors expressing negative Wipl displayed strong staining for p38MAPK (Table III; $r=-0.284)$. In addition, 15 cases $(15 / 26,57.7 \%)$ of negative Wipl exhibited high p16 expression ( $\mathrm{r}=-0.348$; Fig. 3 ). 
Table II. Association between Wip1 expression and clinicopathological factors in 60 patients with non-small cell lung cancer.

\begin{tabular}{|c|c|c|c|c|}
\hline Characteristics & Total & Wip1 positive $(n=38)$ & Wip1 negative $(n=22)$ & P-value \\
\hline \multicolumn{5}{|l|}{ Gender } \\
\hline Male & 34 & 20 & 14 & \\
\hline Female & 26 & 18 & 8 & 0.407 \\
\hline \multicolumn{5}{|c|}{ Lymph node metastasis } \\
\hline NO & 26 & 16 & 10 & \\
\hline $\mathrm{N}+$ & 34 & 22 & 12 & 0.801 \\
\hline \multicolumn{5}{|l|}{ Smoking history } \\
\hline Positive & 28 & 18 & 10 & \\
\hline Negative & 32 & 20 & 12 & 0.886 \\
\hline \multicolumn{5}{|l|}{ Age (years) } \\
\hline$\geqq 60$ & 30 & 18 & 12 & \\
\hline$<60$ & 30 & 20 & 10 & 0.592 \\
\hline \multicolumn{5}{|l|}{ Pathological type } \\
\hline Squamous cancer & 22 & 12 & 10 & \\
\hline Adenocarcinoma & 38 & 26 & 12 & 0.282 \\
\hline \multicolumn{5}{|l|}{ Tumor length (cm) } \\
\hline$>3 \mathrm{~cm}$ & 40 & 30 & 10 & \\
\hline$\leqq 3 \mathrm{~cm}$ & 20 & 8 & 12 & 0.008 \\
\hline \multicolumn{5}{|l|}{ TNM stage } \\
\hline $\mathrm{I} \sim \mathrm{II}$ & 44 & 26 & 18 & \\
\hline III IV & 16 & 12 & 4 & 0.408 \\
\hline \multicolumn{5}{|l|}{ Differentiation } \\
\hline High & 16 & 6 & 9 & \\
\hline Moderate + low & 44 & 32 & 13 & 0.03 \\
\hline \multicolumn{5}{|l|}{ Distant metastasis } \\
\hline Present & 6 & 4 & 2 & \\
\hline Absent & 54 & 34 & 20 & 1 \\
\hline
\end{tabular}

Wip1, wild-type p53 induced phosphatase 1; smoking history, one pack of cigarettes lasts for more than ten years.

Table III. Associations between Wip1, p53, p16 and p38 mitogen-activated protein kinase.

\begin{tabular}{|c|c|c|c|c|c|c|}
\hline \multirow[b]{2}{*}{ Wip1 } & \multicolumn{2}{|c|}{ p53 } & \multicolumn{2}{|c|}{ p16 } & \multicolumn{2}{|c|}{ p38 } \\
\hline & $(+)$ & $(-)$ & $(+)$ & $(-)$ & $(+)$ & $(-)$ \\
\hline$(+)$ & 10 & 25 & 8 & 26 & 8 & 21 \\
\hline$(-)$ & 16 & 9 & 15 & 11 & 19 & 12 \\
\hline $\mathrm{r}$ & \multicolumn{2}{|c|}{-0.352} & \multicolumn{2}{|c|}{-0.348} & \multicolumn{2}{|c|}{-0.284} \\
\hline
\end{tabular}

Wip1, wild-type p53 induced phosphatase 1.

\section{Discussion}

Oncogene activation and cancer suppressor gene inactivation are the key factors of tumor initiation and progression. As previously reported, the Wipl gene has been identified as one of the p53 target genes induced by ionizing radiation (2), which inhibits the activity of p53 (7), downregulated the expression of p38 mitogen activated protein kinase (14) and reduced the level of p16 protein levels (15). Increased evidence suggests that Wip1 serves a vital role in human cancer.

In the current study, it was identified that Wip1 was significantly increased in NSCLC tissues when compared with normal tissues. Statistical analysis indicated that the overexpression of Wip1 was notably associated with tumor length and histological differentiation. By contrast, a previous study suggested that Wipl expression was not associated with tumor size and pathological staging (16). It was identified that Wipl expression was increased in the low and moderate differentiation groups when compared with the high differentiation group, which indicates that Wip1 may be a novel prognostic predictor for NSCLC.

Currently, the common treatment for NSCLC is surgical resection, combined with chemotherapy and/or radiotherapy prior and subsequent to surgery. However, the survival rate with this strategy is not satisfactory (17). Therefore, inhibiting positive regulators of cell proliferation, activating tumor suppressors and inducing apoptosis are primary interventional strategies in modern cancer therapy. A previous study indicated 

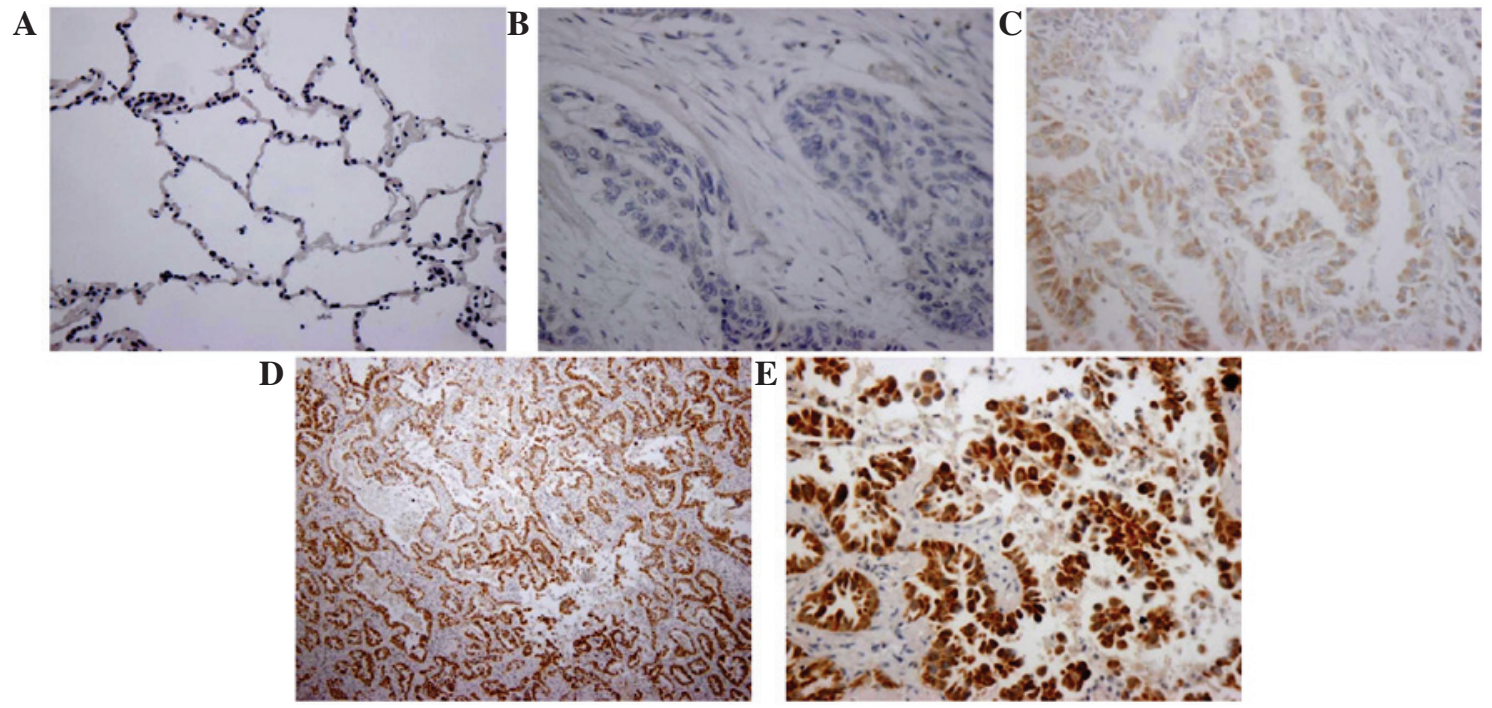

Figure 1. Expression of Wip1 in NSCLC tissues and matched normal tissues. (A) Negative staining of Wip1 in matched normal tissues, $\mathrm{x} 100$. (B and C) Negative staining of Wip1 in NSCLC tissues, x400. (D and E) Positive staining of Wip1 in NSCLC tissues, x100 and x400, respectively. Wip1, wild-type p53 induced phosphatase 1; NSCLC, non-small cell lung cancer.

A

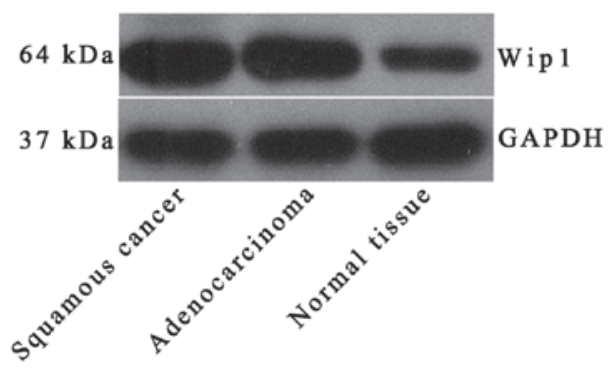

B

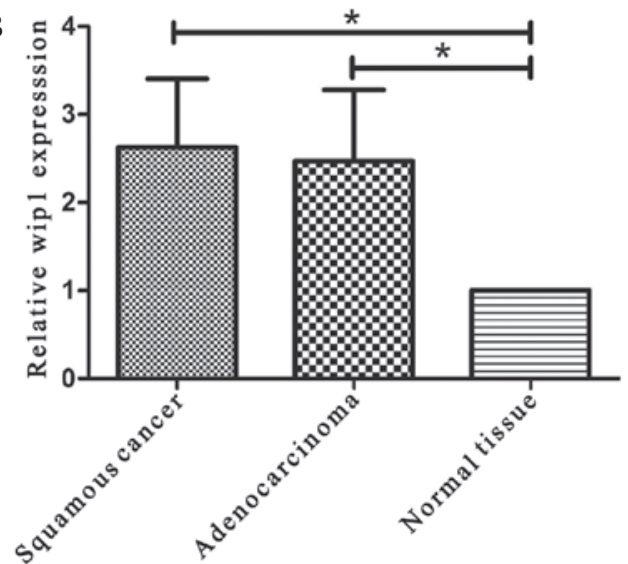

Figure 2. Wip1 protein levels in squamous cancer adenocarcinoma tissuse were significantly upregulated. (A) Representative images western blot analysis results. (B) The quantification of Wip1 protein in different tissue types; GAPDH was set as the endogenous control. " $\mathrm{P}<0.05$. Wip1, wild-type p53 induced phosphatase 1 .

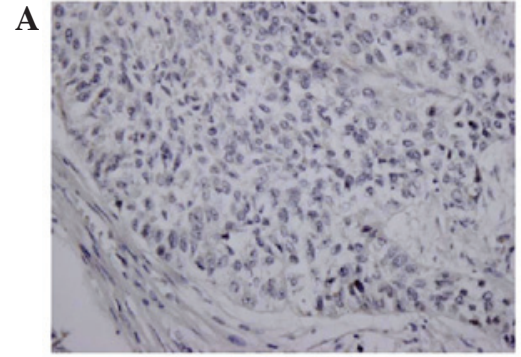

D

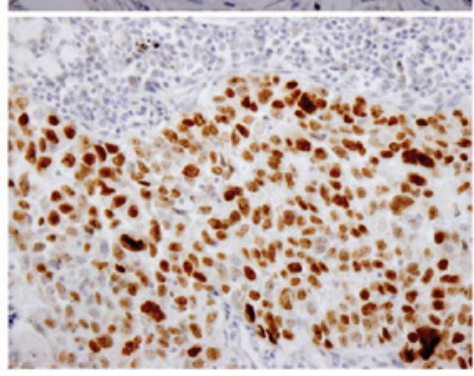

B
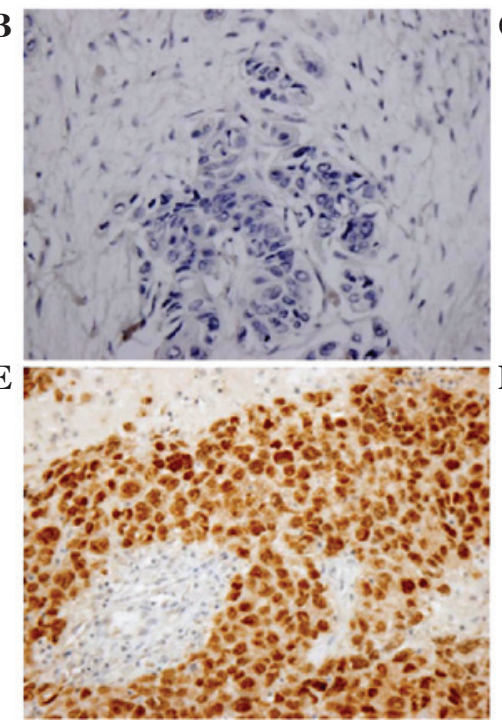
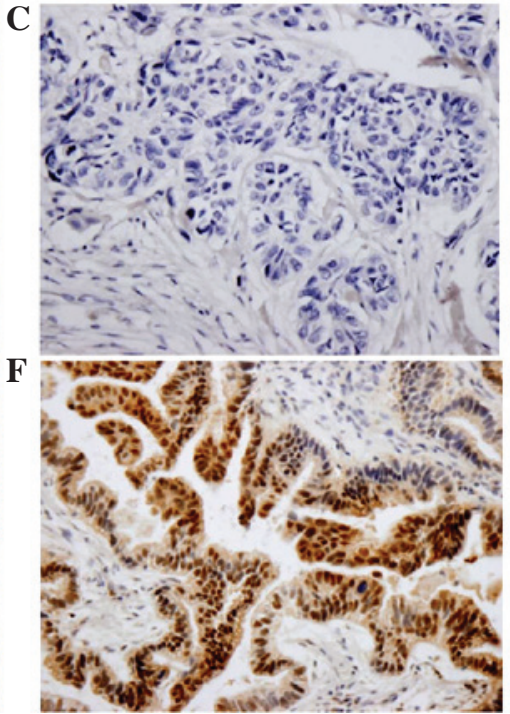

Figure 3. Immunohistochemical staining for p53, p16 and p38MAPK in NSCLC tissues. Negative expression of (A) p53, (B) p16 and (C) p38MAPK in NSCLC tissues. Positive expressions of (D) p53, (E) p16 and (F) p38MAPK in NSCLC tissues. Magnification, 400x. MAPK, mitogen-activated protein kinase; NSCLC, non-small cell lung cancer. 
that Wip1 overexpression in transgenic mice promoted cell transformation and accelerated tumor progression (18). Consistently, another study demonstrated that small interfering RNA knockdown of Wip1 in medulloblastoma cells increased the p53 expression and induced apoptosis $(19,20)$.

Further studies demonstrated that Wip1 overexpression disrupted the homeostasis maintained by the p38MAPK-p53-Wip1 pathway, caused the inactivation of Wnt-p53 through p38MAPK dephosphorylation (15). In the present study, the correlation between the expression of Wip1 and p53, p38MAPK and p16 was investigated in NSCLC tissues. A clear correlation between Wip1 and p38MAPK was observed. In addition, Wip1 expression was observed to be concomitant with reduced p53 levels. These data suggest that Wip1 functionally inactivates p53 and regulates the p38MAPK-p53-Wip1 signal transduction pathway. Previously, Bulavin et al (21) reported that Wip1-null mouse embryonic fibroblasts exhibited significant p16 accumulation and reduced cyclin-dependent kinase 4 activity through p38MAPK signaling in a p53-independent manner.

In summary, the current study demonstrated that Wip1 was frequently overexpressed and associated with the progression of NSCLC, which may serve an essential role in the p38MAPK/p53/p16 signaling pathway.

\section{References}

1. Siegel RL, Miller KD and Jemal A: Cancer statistics, 2015. CA Cancer J Clin 65: 5-29, 2015.

2. Fiscella M, Zhang H, Fan S, Sakaguchi K, Shen S, Mercer WE, Vande Woude GF, O'Connor PM and Appella E: Wip1, a novel human protein phosphatase that is induced in response to ionizing radiation in a p53-dependent manner. Proc Natl Acad Sci USA 94: 6048-6053, 1997.

3. Buss MC, Remke M, Lee J, Gandhi K, Schniederjan MJ, Kool M, Northcott PA, Pfister SM, Taylor MD and Castellino RC: The WIP1 oncogene promotes progression and invasion of aggressive medulloblastoma variants. Oncogene 34: 1126-1140, 2015.

4. Liu S, Qi L, Han W, Wan X, Jiang S, Li Y, Xie Y, Liu L, Zeng F, Liu $\mathrm{Z}$ and $\mathrm{Zu} \mathrm{X}$ : Overexpression of wipl is associated with biologic behavior in human clear cell renal cell carcinoma. PLoS One 9: e110218, 2014.

5. Li ZT, Zhang L, Gao XZ, Jiang XH and Sun LQ: Expression and significance of the Wipl proto-oncogene in colorectal cancer. Asian Pac J Cancer Prev 14: 1975-1979, 2013.

6. Ruark E, Snape K, Humburg P, Loveday C, Bajrami I, Brough R, Rodrigues DN, Renwick A, Seal S, Ramsay E, et al: Mosaic PPM1D mutations are associated with predisposition to breast and ovarian cancer. Nature 493: 406-410, 2013.
7. Bulavin DV, Demidov ON, Saito S, Kauraniemi P, Phillips C, Amundson SA, Ambrosino C, Sauter G, Nebreda AR, Anderson CW, et al: Amplification of PPM1D in human tumors abrogates p53 tumor-suppressor activity. Nat Genet 31: 210-215, 2002 .

8. Dudgeon C, Shreeram S, Tanoue K, Mazur SJ, Sayadi A, Robinson RC, Appella E and Bulavin DV: Genetic variants and mutations of PPM1D control the response to DNA damage. Cell Cycle 12: 2656-2664, 2013

9. FilipponiD,Muller J,Emelyanov A and Bulavin DV: Wip1 controls global heterochromatin silencing via ATM/BRCA1-dependent DNA methylation. Cancer Cell 24: 528-541, 2013.

10. Casanovas O, Miró F, Estanyol JM, Itarte E, Agell N and Bachs O: Osmotic stress regulates the stability of cyclin D1 in a p38SAPK2-dependent manner. J Biol Chem 275: 35091-35097, 2000.

11. Lee JS, Lee MO, Moon BH, Shim SH, Fornace AJ Jr and Cha HJ: Senescent growth arrest in mesenchymal stem cells is bypassed by Wip1-mediated downregulation of intrinsic stress signaling pathways. Stem Cells 27: 1963-1975, 2009.

12. Liao Q, Guo X, Li X, Xiong W, Li X, Yang J, Chen P, Zhang W, Yu H, Tang H, et al: Prohibitin is an important biomarker for nasopharyngeal carcinoma progression and prognosis. Eur $\mathrm{J}$ Cancer Prev 22: 68-76, 2013.

13. Goldstraw P, Crowley J, Chansky K, Giroux DJ, Groome PA, Rami-Porta R, Postmus PE, Rusch V, Sobin L; Internation Association for the Study of Lung Cancer: The IASLC Lung Cancer Staging Project: Proposals for the revision of the TNM stage groupings in the forthcoming (seventh) edition of the TNM classification of malignant tumours. J Thorac Oncol 2: 706-714, 2007.

14. Koom WS, Park SY, Kim W, Kim M, Kim JS, Kim H, Choi IK, Yun $\mathrm{CO}$ and Seong J: Combination of radiotherapy and adenovirus-mediated p53 gene therapy for MDM2-overexpressing hepatocellular carcinoma. J Radiat Res 53: 202-210, 2012.

15. Saito-Ohara F, Imoto I, Inoue J, Hosoi H, Nakagawara A, Sugimoto T and Inazawa J: PPM1D is a potential target for $17 \mathrm{q}$ gain in neuroblastoma. Cancer Res 63: 1876-1883, 2003.

16. Yang DH, He JA, Li J, Ma WF, Hu XH, Xin SJ and Duan ZQ: Expression of proto-oncogene Wip1 in breast cancer and its clinical significance. Zhonghua Yi Xue Za Zhi 90: 519-522, 2010 (In Chinese).

17. Sculier JP: Nonsmall cell lung cancer. Eur Respir Rev 22: 33-36, 2013.

18. Tarulli GA, De Silva D, Ho V, Kunasegaran K, Ghosh K, Tan BC, Bulavin DV and Pietersen AM: Hormone-sensing cells require Wip1 for paracrine stimulation in normal and premalignant mammary epithelium. Breast Cancer Res 15: R10, 2013.

19. Xu H, Liu C, Zhao Z, Gao N, Chen G, Wang Y and Cui J: Clinical implications of GRHL3 protein expression in breast cancer. Tumour Biol 35: 1827-1831, 2014.

20. Yang D, Zhang H, Hu X, Xin S and Duan Z: Abnormality of $\mathrm{pl6} / \mathrm{p} 38 \mathrm{MAPK} / \mathrm{p} 53 / \mathrm{Wipl}$ pathway in papillary thyroid cancer. Gland Surg 1: 33-38, 2012.

21. Bulavin DV, Phillips C, Nannenga B, Timofeev O, Donehower LA, Anderson CW, Appella E and Fornace AJ Jr: Inactivation of the Wipl phosphatase inhibits mammary tumorigenesis through p38 MAPK-mediated activation of the p16 (Ink4a)-p19 (Arf) pathway. Nat Genet 36: 343-350, 2004. 